\title{
Human-wildlife interactions and attitudes towards wildlife and wildlife reserves in Rajasthan, India
}

\author{
Krithi K. Karanth, Shivangi Jain and Erika Weinthal
}

\begin{abstract}
Human-wildlife interactions affect people's livelihoods, attitudes and tolerance towards wildlife and wildlife reserves. To investigate the effect of such interactions on people's attitudes and livelihoods, we surveyed 2,233 households located around four wildlife reserves in Rajasthan, India. We modelled respondents' attitudes towards wildlife and wildlife reserves, experience of crop damage and livestock predation, and likelihood of mitigation use. Crop damage was reported by $76 \%$ of surveyed households, and livestock predation was reported by $15 \%$. Seventy-one percent of households used at least one of eight mitigation measures against crop damage, and $19 \%$ used at least one of seven mitigation measures against livestock predation. We found that male respondents and households with a higher level of education valued wildlife and wildlife reserves more. Households at higher elevations and growing a greater variety of crops were more prone to crop damage. Proximity to reserves, elevation and larger livestock herds were associated with a higher incidence of livestock predation. Households in which a member had $>12$ years of schooling and households with a history (6-10 years) of interaction with wildlife (i.e. crop damage) were most likely to use mitigation against crop damage. Households that owned more livestock and had a history of interaction ( $1-5$ years and $>10$ years) were most likely to mitigate against predation. Our comparative study provides insights into factors that influence interaction and tolerance, which could be used to improve existing management and prevention efforts in Rajasthan.
\end{abstract}

Keywords Compensation, crop damage, human-wildlife interaction, India, livestock predation, mitigation, Rajasthan, tolerance

Supplementary material for this article can be found at https://doi.org/10.1017/So030605317001028

KRITHI K. KaRANTH* (Corresponding author) Wildlife Conservation Society, New York, USA. Email krithi.karanth@gmail.com

ShivangI JAIN Centre for Wildlife Studies, 1669, 31st cross, 16th main, Banashankari 2nd stage, Bengaluru, 560070, India

ERIKA WeINTHAL Nicholas School of Environment, Duke University, Durham, USA

*Also at: Nicholas School of Environment, Duke University, Durham, USA, and Centre for Wildlife Studies, Bengaluru, India

Received 6 January 2017. Revision requested 24 March 2017.

Accepted 9 June 2017. First published online 21 December 2017.

\section{Introduction}

Tnteractions between people and wildlife can be positive, neutral or negative (Redpath et al., 2015; Fisher, 2016). Positive interactions include benefits such as pollination, seed dispersal services, pest management and tourism (Zhang et al., 2007). Negative interactions include loss of property, crops, livestock, and human lives, and pose a significant challenge to conservation efforts in wildlife reserves (Fernando et al., 2005; Naughton-Treves \& Treves, 2005). Such losses incurred by vulnerable communities can lead to a decreased tolerance for wildlife and may result in retaliatory killings (Ogada et al., 2003; Holmern et al., 2007; Kissui, 2008). Ongoing land-use change and sharing of resources between wildlife and people make it imperative to understand the nature of these interactions, to mitigate losses on both sides and foster tolerance.

Understanding the agricultural and livestock husbandry practices that predispose communities to crop damage and livestock predation can facilitate better mitigation efforts (Woodroffe et al., 2007). Commonly used physical preventive mitigation measures include electric, solar and deterrent crop fences, trenches, night-watching, scare devices and livestock-protection dogs (Davies et al., 2011; Karanth et al., 2012). Reactive measures include insurance and post hoc compensation schemes (Ogra \& Badola, 2008; Treves et al., 2009). Understanding which factors influence a household's decisions to use mitigation measures is important for managing negative interactions (Ogada et al., 2003; Karanth \& Kudalkar, 2017).

India provides an ideal context to study human-wildlife interactions because damage to crops and livestock is widespread across various geographical, cultural and ecological contexts (Karanth \& Kudalkar, 2017; Karanth \& Surendhra, 2018). Wildlife such as wild pigs Sus scrofa, nilgai Boselaphus tragocamelus and elephants Elephas maximus are common causes of crop damage, whereas tigers Panthera tigris, leopards Panthera pardus and canids are associated with livestock losses (Karanth et al., 2010; Karanth \& Surendhra, 2018).

During 2010-2015 compensation was awarded in $>81,100$ cases of reported conflict across India (Karanth \& Gupta, unpubl. data). This number is probably an underestimate, as many incidents are not reported (Ogra \& Badola, 2008; Karanth et al., 2012; Dhanwatey et al., 2013; Karanth et al., 2013a, b). Crop and property damage is the most common $(71 \%)$, followed by livestock predation $(21 \%)$, with fewer incidents of human injury $(6 \%)$ and death $(<0.4 \%)$ (Karanth \& Gupta, unpubl. data). 
In contrast to other Indian states, Rajasthan does not have a policy for crop damage but provides compensation payments for livestock loss, human injury and death (Johnson et al., unpubl. data; Karanth \& Gupta, unpubl. data). Given the juxtaposition of wildlife and people in the state, understanding people's attitudes towards wildlife and wildlife reserves is essential to wildlife conservation efforts. We investigated attitudes towards wildlife-related loss of crops and livestock, damage to property, and human injury and death, among people living near four reserves. We also examined factors that influence the use of mitigation measures, and experiences with compensation. We sought to understand people's attitudes towards wildlife, reserves and wildlife-related losses, and in doing so to influence existing park management policies and practices in Rajasthan.

\section{Study area}

We selected four relatively understudied non-tiger reserves in Rajasthan state: Jaisamand Wildlife Sanctuary, Kumbhalgarh \& Todgarh Raoli Wildlife Sanctuary, Phulwari ki Nal Wildlife Sanctuary and Sitamata Wildlife Sanctuary, hereafter Jaisamand, Kumbhalgarh, Phulwari and Sitamata, respectively (Table 1; Fig. 1). Vegetation in these reserves comprises mainly dry deciduous forests and scrublands (Robbins et al., 2009), and the reserves support populations of wolves Canis lupus, leopards, sloth bears Melursus ursinus, hyaenas Hyaena hyaena, and ungulates such as the sambar Cervus unicolor, spotted deer Axis axis, nilgai and four horned antelope Tetracerus quadricornis (Chhangani et al., 2008; Robbins et al., 2009). The settlements around the reserves are agropastoral, depending on livestock husbandry, subsistence and commercial agriculture (Chhangani et al., 2008).

\section{Methods}

\section{Household surveys}

During January-March 2014 trained volunteers and research assistants surveyed 2,233 households in 1,096 villages within a radius of $10 \mathrm{~km}$ of the four study reserves (Table 1 ). This radius was chosen based on the known movement of wildlife outside reserve boundaries (Chhangani et al., 2008; Robbins et al., 2009; Karanth et al., 2013a, b). We divided the study area $\left(9,920 \mathrm{~km}^{2}\right)$ into 620 grid cells and surveyed households in 502 cells, excluding 118 that did not contain any households (Table 1). Respondents answered structured, semi-structured and open-ended questions in Hindi. Informed consent was obtained verbally from each respondent prior to administering the survey and using the data. We were unable to obtain written consent because respondents had low levels of literacy and were uncomfortable signing documents.
Adult respondents were questioned about their attitudes towards wildlife and the wildlife reserves. They provided information on family size, education levels, agricultural practices, land and livestock ownership, animal husbandry practices, and access to communal lands. Specifically, respondents were asked about their household's negative interactions with wildlife (damage to crops or property, livestock predation, human injury or death), following protocols described in Karanth et al. (2012, 2013a). The questions regarding these interactions were restricted to the most recent year, to minimize recall errors. We also enquired about the use of mitigation measures, and access to and reporting of compensation. In addition to the variables derived from the survey data, we also derived distance to the closest wildlife reserve, distance to the closest water body and elevation for each household, to serve as landscape predictors in our models in ArcGIS 10.4 (ESRI, Redlands, USA). We used the land use/land cover information from the Natural Resources Census Project of the National Remote Sensing Centre (2014), and elevation data from the Advanced Spaceborne Thermal Emission and Reflection Radiometer Global Digital Elevation Map available through the NASA Land Processes Distributed Active Archive Center (NASA, 2011).

\section{Variable and model selection}

We selected nine variables of interest for attitudes towards wildlife and wildlife reserves, 17 for crop damage, 13 for livestock predation, 15 for mitigation against crop damage, and 12 for mitigation against livestock predation (Supplementary Table S1). We calculated Pearson's correlations for the covariates to check for collinearity (Pearson, 1895).

To model household attitudes towards wildlife and wildlife reserves we questioned respondents about the importance of protecting wildlife reserves, and whether they would value wildlife more in the absence of negative interactions. We expected positive associations for male respondents, owning more agricultural land, and more years of schooling, and for households that experienced fewer negative interactions (Browne-Nuñez et al., 2013; Karanth \& Kudalkar, 2017).

To model crop damage and use of mitigation against crop damage, we used only data from 2,095 households that grew crops. Similarly, to model livestock predation and use of mitigation against livestock predation we used only data from 1,981 households that owned livestock. As our response variables were binary, we constructed binary logistic regression models to parse out the effects of our covariates.

We expected households that were closer to the reserves and water bodies to experience more crop damage and livestock predation (Chhangani et al., 2008; Dhanwatey et al., 
TABLE 1 Characteristics of Jaisamand, Kumbhalgarh \& Todgarh Raoli, Phulwari ki Nal, and Sitamata Wildlife Sanctuaries in Rajasthan, India (Fig. 1), with details of the household surveys conducted during January-March 2014 to investigate attitudes towards wildlife and wildlife reserves.

\begin{tabular}{|c|c|c|c|c|}
\hline & Jaisamand & Kumbhalgarh & Phulwari & Sitamata \\
\hline Year of establishment & 1955 & 1971 & 1983 & 1979 \\
\hline Area $\left(\mathrm{km}^{2}\right)$ & 152 & 1,106 & 1,841 & 419 \\
\hline Districts & Udaipur & $\begin{array}{l}\text { Ajmer, Pali, Rajsamand, } \\
\text { Udaipur }\end{array}$ & Udaipur & $\begin{array}{l}\text { Chittaurgarh, Pratapgarh, } \\
\text { Udaipur }\end{array}$ \\
\hline Human density (individuals $\left.\mathrm{km}^{-2}\right)^{1}$ & $207-611$ & $111-522$ & $111-611$ & $128-1,301$ \\
\hline Livestock density (individuals $\left.\mathrm{km}^{-2}\right)^{2}$ & 207 & $186-292$ & 207 & $127-207$ \\
\hline Total area surveyed $\left(\mathrm{km}^{2}\right)$ & 622 & 3,084 & 2,022 & 778 \\
\hline Total no. of grid cells & 50 & 290 & 196 & 84 \\
\hline No. of grid cells surveyed & 48 & 238 & 156 & 60 \\
\hline No. of villages surveyed & 109 & 494 & 350 & 143 \\
\hline No. of households surveyed & 221 & 1,046 & 683 & 283 \\
\hline Mean no. of household members (range) & $7(1-26)$ & $7(0-32)$ & $8(1-29)$ & $6(0-26)$ \\
\hline \multicolumn{5}{|l|}{ Gender (\%) } \\
\hline Male & 74 & 80 & 73 & 83 \\
\hline Female & 26 & 19 & 27 & 17 \\
\hline \multicolumn{5}{|l|}{ Education (\%) } \\
\hline Illiterate & 6 & 7 & 13 & 11 \\
\hline Primary & 30 & 28 & 28 & 34 \\
\hline Secondary & 47 & 50 & 45 & 44 \\
\hline College & 17 & 14.5 & 14 & 10 \\
\hline Agricultural land ownership (\%) & 96 & 88 & 97.5 & 95 \\
\hline Mean agricultural land per household, acres (range) & $1(0-21)$ & $1(0-52)$ & $1(0-17)$ & $1(0-17)$ \\
\hline Non-agricultural land ownership (\%) & 32 & 42 & 26 & 24 \\
\hline Mean non-agricultural land per household, acres (range) & $0.30(0-5)$ & $0.5(0-12.5)$ & $0.35(0-37)$ & $0.30(0-16)$ \\
\hline Households that report communal land-use restrictions (\%) & 15 & 17 & 24 & 12 \\
\hline \multicolumn{5}{|l|}{ Livestock ownership (\%) } \\
\hline Cattle & 72 & 55 & 77 & 71 \\
\hline Buffalo & 56 & 53 & 47 & 52 \\
\hline Goats & 38 & 58 & 69 & 56.5 \\
\hline Sheep & 0.5 & 3 & 3 & 2 \\
\hline Pigs & 0 & 0 & 0.15 & 0 \\
\hline Camels & 0 & 0.5 & 0.15 & 0 \\
\hline \multicolumn{5}{|l|}{$\%$ livestock owners who graze their livestock in: } \\
\hline Hills & 18 & 19 & 14 & 0.8 \\
\hline Forest & 4 & 3 & 26 & 0 \\
\hline Communal land & 3 & 11.5 & 0.3 & 0 \\
\hline Agricultural land & 8 & 4.5 & 4 & 0 \\
\hline Other & 0 & 3 & 0.5 & 0 \\
\hline
\end{tabular}

${ }^{1}$ Government of India (2011)

${ }^{2}$ Government of India (2012) 


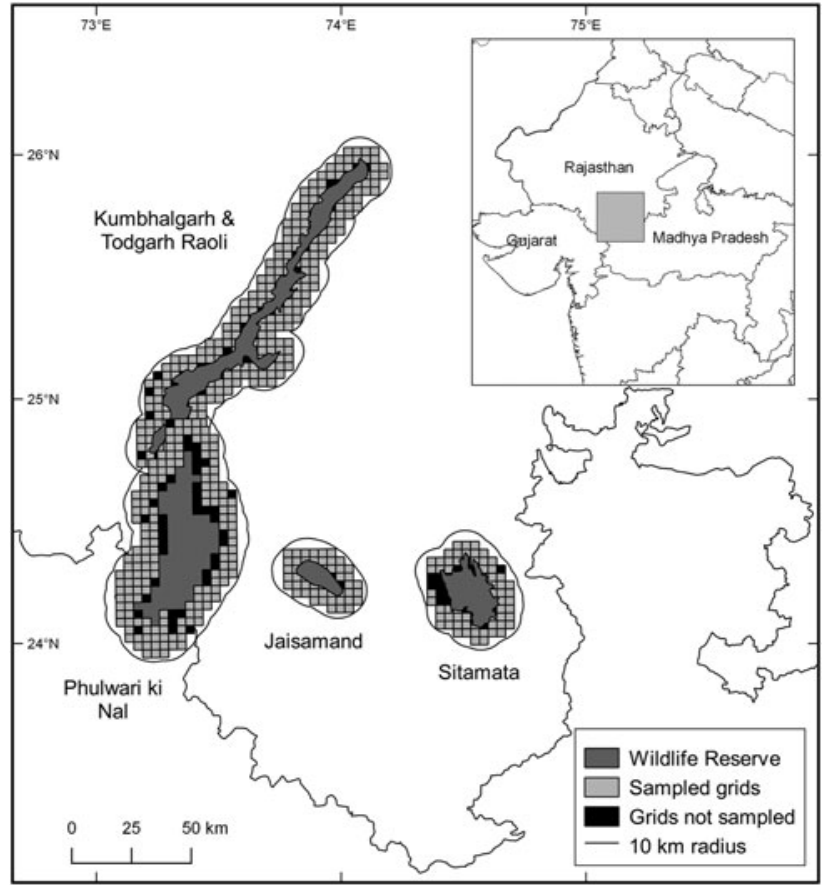

FIG. 1 Location of Jaisamand, Kumbhalgarh \& Todgarh Raoli, Phulwari ki Nal, and Sitamata Wildlife Sanctuaries in Rajasthan, India.

2013; Karanth, 2016; Karanth \& Surendhra, 2018). For crop damage, we expected households growing a greater variety of crops and with larger land holdings to experience more raiding (Chhangani et al., 2008; Karanth \& Surendhra, 2018). Additionally, we expected larger households using more mitigation measures to experience less raiding (Davies et al., 2011; Karanth et al., 2012, 2013a,b). We predicted households owning larger herds of livestock and using communal lands for grazing would experience higher levels of livestock predation (Bradley \& Pletscher, 2005; Michalski et al., 2006; Chhangani et al., 2008). We also expected predation would be negatively associated with a higher number of mitigation measures and household members (Karanth et al., 2012, 2013a).

We anticipated that use of mitigation against crop damage would be positively associated with households owning more agricultural land, growing a greater variety of crops, having a longer history of negative interactions, having more members and being more educated (Fernando et al., 2005; Sitati et al., 2005; Karanth \& Nepal, 2012; Karanth \& Kudalkar, 2017). Similarly, we predicted that use of mitigation against livestock predation would be positively associated with households owning more agricultural land and larger livestock herds, having a longer history of negative interactions, having more members and being more educated (Karanth \& Nepal, 2012; Karanth \& Kudalkar, 2017). We also anticipated a negative association of mitigation use and distance to the reserve (Karanth \& Kudalkar, 2017).
We built a priori models for each of the six response variables, assessed their fit using Akaike's information criterion corrected for a small sample size (AICc), and identified significantly associated variables (Burnham \& Anderson, 2002). Using the AICc weights to assess a model's fit relative to its parsimony, we selected our top models. Based on a priori predictions, we constructed 15 models for crop damage, 15 for livestock predation, 15 for mitigation against crop damage, 14 for mitigation against livestock predation, six for importance of wildlife reserves and six for whether the household would value wildlife more in the absence of negative interactions. We used the top models (cumulative AICc weights $>0.95$ ) to calculate the probability estimate of each of the response variables.

\section{Results}

\section{General household characteristics}

Despite sustained efforts to include more women in our surveys, $78 \%$ of respondents were men (Table 1 ). The majority of households $(62 \%)$ included a member with $>8$ years of school education (Table 1). Most households (93\%) reported owning a mean of 0.4 ha (range $0-21$ ha) of agricultural land (ranging from $88 \%$ in Kumbhalgarh to $97.5 \%$ in Phulwari).

Twenty-eight percent of households reported the existence of communal land in their community (ranging from 9\% in Phulwari to $42 \%$ in Kumbhalgarh), used primarily for grazing domestic animals. Among these, $17 \%$ reported that there were restrictions on the use of communal land, such as open/closed seasons and limits on fuelwood collection (ranging from $12 \%$ in Sitamata to $24 \%$ in Phulwari).

The majority (77.5\%) of surveyed households reported they had experienced negative human-wildlife interactions, such as losses of crops, livestock and/or property, in the preceding year (ranging from $69 \%$ in Phulwari to $83 \%$ in Jaisamand). For $50 \%$ of respondents the frequency of interaction seemed to increase during periods with less rainfall.

\section{Attitudes towards wildlife and wildlife reserves}

Many respondents believed that protecting wildlife reserves for wild animals was important $(85 \%)$ and stated they would value wildlife more in the absence of negative interactions and losses (73\%) (Supplementary Table S2). We explored factors associated with households' support for protection of wildlife reserves. As expected, our two top-ranked models suggested that females were more likely to have negative associations compared to males $(\beta=-0.32 \pm \mathrm{SE} 0.15$; Supplementary Table $S_{3}$ ). As predicted, respondents with more education were more supportive of protecting wildlife reserves for animals $(\beta$ range $=0.47-0.81, \mathrm{SE}=0.21-0.26$ ). We estimated that the probability of a household supporting 
the protection of wildlife reserves was $0.85 \pm \mathrm{SE} 0.02$ (Table 2). Households in Sitamata were significantly more supportive than those in other reserves (ANOVA test, $\mathrm{P}<0.05)$.

We also examined whether in the absence of negative interactions households would value wildlife and its protection more, and found one top-ranked model (Supplementary Table S3). In comparison to Kumbhalgarh, households around Phulwari $(\beta=-1.32 \pm$ SE 0.14 $)$ and Sitamata $(\beta=-0.86 \pm \mathrm{SE} 0.18)$ were less likely and households around Jaisamand $(\beta=0.52 \pm$ SE 0.26$)$ were more likely to value wildlife in the absence of negative interactions. Absence of negative interactions with wildlife was less likely to improve women's tolerance for wildlife compared to men's $(\beta=-0.36 \pm \mathrm{SE} 0.14)$. As expected, education was positively associated with valuing wildlife $(\beta$ range $=0.62-1.16)$. Furthermore, households that experienced crop damage $(\beta=1.53 \pm \mathrm{SE} 0.17)$ and livestock predation $(\beta=0.84 \pm$ SE 0.21 ), and used mitigation, were positively associated with valuing wildlife in the absence of negative interactions $(\beta=0.65 \pm \mathrm{SE} 0.16)$. The estimated probability of a household's value for wildlife increasing in the absence of negative interactions was $0.74 \pm \mathrm{SE} 0.03$, ranging from $0.55 \pm \mathrm{SE} 0.04$ in Phulwari to $0.89 \pm$ SE 0.02 in Jaisamand. The probabilities differed significantly among the reserves (ANOVA test, $\mathrm{P}<0.05)$.

\section{Crop and property damage}

Households cultivated $>22$ crops, including both food and non-food crops, such as cereals (92\%), pulses and legumes $(51 \%)$, oilseeds $(42 \%)$, millets $(20 \%)$ and cotton (10\%). Many households $(47 \%)$ reported having changed their farming practices in the previous 10 years. Crop production was most affected by lack of rain (89\%) and irrigation (71\%), whereas farming practices were changed depending on the availability of and access to development assistance (28\%), new markets (11\%), input factors ( $11 \%)$ and government support (10\%).

Many households ( $76 \%$ ) reported experiencing crop damage, ranging from $69 \%$ in Phulwari to $83 \%$ in Jaisamand (Supplementary Table S2), with a statistically significant difference in crop damage across reserves (Fisher test, $\mathrm{P}<0.05$ ). Respondents attributed crop damage to 20 species, the top-ranked being nilgai (75\%), jackal Canis aureus (28\%) and wild pig (28\%) (Supplementary Table S2). A majority of households (91\%) that experienced crop damage were affected in July and August. The frequency of crop damage was high, with $89 \%$ of households experiencing $>10$ incidents per year. The difference in history of crop damage between reserves was statistically significant (Fisher test, $\mathrm{P}<0.05$ ).

Although levels of crop damage varied, $47 \%$ of respondents reported losing $26-50 \%$ of their crop in the previous year. The subsequent loss of income from crop damage amounted to a mean of USD 164 (INR 11,00o), with a maximum loss of USD 14,925 (INR 1,000,000 at USD $1=$ INR 67) (Supplementary Table S2). Losses experienced by households around Phulwari were significantly lower compared to the other three reserves (ANOVA test, $\mathrm{P}<0.05$ ). Property damage was rare, being reported by a single household in Kumbhalgarh.

We modelled household vulnerability to crop damage and found six top-ranked models (cumulative AICc weight $>0.95$ ) (Supplementary Table S5). Contrary to expectations, households located at higher elevations were found to be positively associated with higher levels of crop damage $\left(\beta=0.73 \pm\right.$ SE o.16) (Supplementary Table $\left.S_{3}\right)$. As predicted, we observed that households that grew more crops suffered more crop damage $(\beta=0.92 \pm \mathrm{SE} 0.20)$. However, crop damage was also positively associated with households that used mitigation measures against crop damage $(\beta=4.02 \pm \mathrm{SE} 0.17)$. We did not find any other factors of significance associated with crop damage among our top-ranked models. The mean estimated probability of crop damage was $0.79 \pm \mathrm{SE} 0.01$ across all four reserves, ranging from $0.67 \pm \mathrm{SE}$ 0.02 in Phulwari to $0.86 \pm$ SE 0.01 in Kumbhalgarh. The estimates for Phulwari were significantly lower than those for the other three reserves (ANOVA test, $\mathrm{P}<0.05$ ).

\section{Livestock predation}

The majority of households surveyed (89\%) owned livestock, ranging from $83 \%$ in Kumbhalgarh to $92 \%$ in Phulwari. There was no significant shift in livestock ownership during the 10 years prior to the survey. Fifteen percent of surveyed households reported experiencing a livestock predation incident in the previous year (Supplementary Table S2). The difference in livestock predation reported between the four reserves was statistically significant (Fisher test, $\mathrm{P}<0.95)$. Predation was attributed to eight species, the most important being leopards (56\%), jackals (27\%) and wolves (12\%) (Supplementary Table S2). The frequency of predation incidents varied from once per year $(40 \%)$ to $>10$ times per year $(16 \%)$. The subsequent loss of income from livestock predation amounted to a mean of USD 69 (INR 4,600), with a maximum loss of USD 1,492 (INR 100,000). Kumbhalgarh experienced significantly greater losses than Phulwari and Sitamata, and similar losses to Jaisamand (ANOVA, $\mathrm{P}<0.05$ ).

We modelled the risk of livestock loss and found four top-ranked models (cumulative AICc weights $>0.95$ ) (Supplementary Table S6). Among the landscape factors, as expected, distance to reserve had a negative association $(\beta=-0.35 \pm$ SE 0.15) and elevation had a positive association $(\beta=0.52 \pm$ SE 0.16$)$ with livestock predation (Supplementary Table $S_{3}$ ). Ownership of 6-10 head of livestock 
TABLE 2 Estimated proportions using top ranked models $( \pm$ SE) of positive attitudes towards wildlife and wildlife reserves, crop damage, livestock loss and mitigation use in Jaisamand, Kumbhalgarh \& Todgarh Raoli, Phulwari ki Nal, and Sitamata Wildlife Sanctuaries in Rajasthan, India (Fig. 1).

\begin{tabular}{|c|c|c|c|c|c|c|}
\hline Type & & Jaisamand & Kumbhalgarh & Phulwari & Sitamata & All reserves \\
\hline Important to protect wildlife reserves & $\begin{array}{l}\text { Mean } \\
\text { (Range) }\end{array}$ & $\begin{array}{l}0.86 \pm 0.02 \\
(0.71-0.91)\end{array}$ & $\begin{array}{l}0.85 \pm 0.02 \\
(0.69-0.95)\end{array}$ & $\begin{array}{l}0.83 \pm 0.02 \\
(0.68-0.91)\end{array}$ & $\begin{array}{l}0.87 \pm 0.02 \\
(0.75-0.93)\end{array}$ & $\begin{array}{l}0.85 \pm 0.02 \\
(0.68-0.95)\end{array}$ \\
\hline Value wildlife more in the absence of interaction & $\begin{array}{l}\text { Mean } \\
\text { (Range) }\end{array}$ & $\begin{array}{l}0.89 \pm 0.02 \\
(0.38-0.98)\end{array}$ & $\begin{array}{l}0.84 \pm 0.02 \\
(0.26-0.98)\end{array}$ & $\begin{array}{l}0.55 \pm 0.04 \\
(0.09-0.90)\end{array}$ & $\begin{array}{l}0.68 \pm 0.04 \\
(0.14-0.94)\end{array}$ & $\begin{array}{l}0.74 \pm 0.03 \\
(0.09-0.98)\end{array}$ \\
\hline Experience crop damage & $\begin{array}{l}\text { Mean } \\
\text { (Range) }\end{array}$ & $\begin{array}{l}0.83 \pm 0.01 \\
(0.19-0.96)\end{array}$ & $\begin{array}{l}0.86 \pm 0.01 \\
(0.11-0.98)\end{array}$ & $\begin{array}{l}0.67 \pm 0.02 \\
(0.12-0.97)\end{array}$ & $\begin{array}{l}0.80 \pm 0.01 \\
(0.17-0.97)\end{array}$ & $\begin{array}{l}0.79 \pm 0.01 \\
(0.11-0.98)\end{array}$ \\
\hline Experience livestock loss & $\begin{array}{l}\text { Mean } \\
\text { (Range) }\end{array}$ & $\begin{array}{l}0.10 \pm 0.01 \\
(0.02-0.66)\end{array}$ & $\begin{array}{l}0.24 \pm 0.03 \\
(0.02-0.87)\end{array}$ & $\begin{array}{l}0.10 \pm 0.01 \\
(0.02-0.79)\end{array}$ & $\begin{array}{l}0.13 \pm 0.02 \\
(0.02-0.73)\end{array}$ & $\begin{array}{l}0.17 \pm 0.02 \\
(0.02-0.87)\end{array}$ \\
\hline Mitigate against crop damage & $\begin{array}{l}\text { Mean } \\
\text { (Range) }\end{array}$ & $\begin{array}{l}0.85 \pm 0.03 \\
(0.54-0.93)\end{array}$ & $\begin{array}{l}0.87 \pm 0.02 \\
(0.39-0.94)\end{array}$ & $\begin{array}{l}0.84 \pm 0.03 \\
(0.45-0.93)\end{array}$ & $\begin{array}{l}0.87 \pm 0.02 \\
(0.53-0.93)\end{array}$ & $\begin{array}{l}0.86 \pm 0.02 \\
(0.39-0.94)\end{array}$ \\
\hline Mitigate against livestock loss & $\begin{array}{l}\text { Mean } \\
\text { (Range) }\end{array}$ & $\begin{array}{l}0.14 \pm 0.02 \\
(0.05-0.93)\end{array}$ & $\begin{array}{l}0.28 \pm 0.03 \\
(0.05-0.97)\end{array}$ & $\begin{array}{l}0.14 \pm 0.02 \\
(0.05-0.95)\end{array}$ & $\begin{array}{l}0.17 \pm 0.02 \\
(0.05-0.89)\end{array}$ & $\begin{array}{l}0.21 \pm 0.02 \\
(0.05-0.97)\end{array}$ \\
\hline
\end{tabular}

$(\beta=0.62 \pm \mathrm{SE} 0.24)$ and $>20$ head of livestock $(\beta=1.11 \pm \mathrm{SE}$ o.34) had significant positive association with the risk of predation. Mitigation use was also strongly positively associated with livestock predation $(\beta=3.26 \pm$ SE o.16). The mean estimated probability of livestock predation ranged from 0.1 in Phulwari $(\mathrm{SE}=0.012)$ to 0.24 in Kumbhalgarh $(\mathrm{SE}=0.03)$ and was significantly higher for the latter in comparison to the other three reserves (ANOVA test, $\mathrm{P}<0.05)$.

\section{Human injury and death}

Incidents of human injury were rare $(0.3 \%$ in Phulwari and $0.6 \%$ in Kumbhalgarh), and were most frequent during December, January and February (Supplementary Table S2). Injuries were attributed to wolves (25\%), leopards (25\%), hyaenas (25\%), sloth bears (25\%), wild pigs (12.5\%), nilgai $(12.5 \%)$, and four-horned antelope (12.5\%).

\section{Mitigation measures}

We questioned householders regarding their use of mitigation measures to protect their crops, livestock and themselves. To mitigate against crop damage, night-time watching was used by $57 \%$ of households, followed by lighting and scare devices (48\%), fencing (42\%), use of guard animals (22\%) and removal of bush and forest (12\%) (Supplementary Table S2). Use of mitigation against livestock predation was lower, and common measures included watching livestock more closely (15\%) and fencing (8\%) (Supplementary Table S2).

Few householders (18\%) stated that they would act as a group rather than individually to mitigate losses on communal land. Most of these households (89\%) participated in communal mitigation activities by attending community meetings. Many (74\%) stated that they were likely to cooperate with local officials if asked to try specific measures.

We modelled the use of mitigation to reduce crop damage and livestock predation. We found six top-ranked models each for mitigation use against crop damage and against livestock predation (cumulative AICc weight $>$ 0.95) (Supplementary Tables S7 \& S8). In contrast to our predictions, households further away from the reserves were more likely to use mitigation measures against crop damage $(\beta=0.31 \pm \mathrm{SE} 0.16)$. As expected, number of years of crop damage was positively associated with mitigation use, with the association being strongest for 6-10 years $(\beta=1.68 \pm$ SE 0.35). Households whose members had more education were also significantly positively associated with mitigation use $(\beta$ range $=0.49-0.99$, SE range $=0.27-0.34)$. Amongst species responsible for crop damage, the wild pig was the only one that had a significant positive association with mitigation use $(\beta=0.37 \pm \mathrm{SE}$ 0.22). The estimated mean probability of mitigation use against crop damage across the four reserves was $0.86 \pm$ SE 0.02 (Table 2). The probability was relatively similar across the reserves, ranging from $0.84 \pm \mathrm{SE} 0.03$ in Phulwari to $0.87 \pm \mathrm{SE} 0.02$ in Kumbhalgarh and Jaisamand. Estimates for Kumbhalgarh were significantly higher than for the other reserves, and estimates for Phulwari were the lowest among the reserves (ANOVA test, $\mathrm{P}<0.05$ ).

Contrary to our predictions, use of mitigation against livestock predation was positively associated with distance to reserve $(\beta=0.34 \pm \mathrm{SE}$ 0.14). As expected, livestock ownership had a positive association with mitigation use, the relationship being strongest for households with 16-20 head of livestock $(\beta=1.49 \pm \mathrm{SE} 0.44)$. Households that had experienced livestock predation for over a decade $(\beta=1.59 \pm \mathrm{SE} 0.35)$ and for $1-5$ years $(\beta=1.07 \pm \mathrm{SE} 0.42)$ were positively associated with mitigation use. There was a strong positive association between mitigation use by households and the predation of livestock by leopards 
$(\beta=2.29 \pm \mathrm{SE} 0.34)$, wolves $(\beta=2.22 \pm \mathrm{SE} 0.55)$ and jackals $(\beta=1.38 \pm$ SE 0.39). Contrary to our expectations, households including a member with $>12$ years of schooling were less likely to mitigate against livestock predation compared to households whose members were illiterate $(\beta=-0.58 \pm \mathrm{SE} 0.31)$. The estimated mean probability of mitigation use against livestock predation was low $0.21 \pm \mathrm{SE}$ 0.02 ) (Table 2), ranging from $0.14 \pm$ SE 0.02 in Phulwari and Jaisamand to $0.28 \pm \mathrm{SE} 0.03$ in Kumbhalgarh, with the estimate for the latter being the highest among the reserves (ANOVA test, $\mathrm{P}<0.05$ ).

\section{Compensation}

Most households (84\%) that experienced losses did not seek assistance. Furthermore, Rajasthan state does not have a compensation scheme for crop damage (Johnson et al., unpubl. data; Karanth \& Gupta, unpubl. data). Of the 16 households that reported incidents of livestock predation by wildlife to the government, six received compensation. Five households received $<$ USD 15 (INR 1,00o) and one received USD 15-75 (INR 1,000-5,000).

\section{Discussion}

Our household survey data from four reserves in Rajasthan provide insights about the relationships between people, wildlife and reserves. Many respondents (85\%) considered protecting wildlife reserves to be important despite the legal restrictions on resource use, and experiencing negative human-wildlife interactions. We did not find any differences in people's attitudes towards the reserves, but found differences in attitudes towards human-wildlife interaction. Absence of negative interactions was more likely to be correlated with attitudes towards wildlife among households around Jaisamand, compared to Phulwari, Sitamata and Kumbhalgarh. As Jaisamand has the highest incidence of negative interactions, we suggest that supporting households incurring frequent wildlife-related losses could increase their tolerance for wildlife. Similar to findings from Nepal and Tanzania, households with more education were more likely to value wildlife reserves and wildlife in the absence of negative interactions (Holmern et al., 2007; Karanth \& Nepal, 2012). Overall, female respondents viewed both wildlife reserves and wildlife less favourably compared to men. These findings concur with previous research that has found that women sometimes bear a larger burden of wildlife-related losses than men, which results in a negative attitude towards wildlife and wildlife reserves (Ogra \& Badola, 2008; Gore \& Kahler, 2012; Browne-Nuñez et al., 2013).

The mean estimated probability of experiencing wildlife-related crop damage across the four reserves was
0.79. This is similar to Ranthambore National Park (0.76), but lower than estimates from Kanha Tiger Reserve (0.93) and reserves in Karnataka (0.91) (Karanth et al., 2012, 2013a). Distance to the reserve did not influence the occurrence of crop damage significantly, similar to Ranthambore and reserves in Karnataka, where crop-raiding wildlife have been found to exist outside reserves (Karanth et al., 2013a, b). Households at higher elevations were more likely to experience crop damage, unlike in previous studies (Karanth et al., 2012, 2013a, b). Furthermore, households that grew a greater variety of crops were more likely to experience crop damage (Karanth et al., 2012, 2013a).

Our estimated probability of livestock predation in reserves in Rajasthan (0.17) was significantly lower than the estimates from Ranthambore (o.38) and Kanha (o.6o) but comparable to reserves in Karnataka (o.19) (Karanth et al., 2012, 2013a,b). Proximity to the reserves increased the risk of livestock predation, suggesting losses may be associated with carnivores emerging from the reserves, or people grazing livestock inside reserves (Michalski et al., 2006; Karanth et al., 2012, 2013a; Dhanwatey et al., 2013). We also found households at higher elevations or with larger livestock herds were more likely to experience livestock predation, similar to studies from the Amazon and the USA, and a pan-India study of 5,000 households (Bradley \& Pletscher, 2005; Michalski et al., 2006; Karanth et al., 2013a; Karanth \& Kudalkar, 2017). Livestock loss has been found to be positively associated with grazing inside reserves in the Western Ghats, Central India and other parts of the world (Woodroffe et al., 2007; Chhangani et al., 2008; Kissui, 2008; Karanth et al., 2012, 2013a). In Rajasthan, livestock is commonly grazed in high elevation areas and wildlife reserves, and therefore encouraging people to stall-feed could reduce livestock loss.

Unlike in Central India and the Western Ghats, use of mitigation in the study reserves had a positive relationship with occurrence of crop damage and livestock predation, suggesting that either the mitigation measures were ineffective or they were employed as a reactive measure (Davies et al., 2011; Karanth et al., 2012, 2013a). This finding is supported by a parallel study of 11 reserves across India (Karanth \& Surendhra, 2018).

Contrary to our predictions, use of mitigation against both crop and livestock losses was positively associated with distance to reserve. Unexpectedly, although households whose members had more education were more likely to use mitigation against crop damage, the opposite was true in the case of livestock predation (Dickman, 2010). We also confirmed that households with larger herds were more likely to use mitigation. Additionally, the uptake of mitigation against crop damage and livestock predation was highest for households reporting 6-10 years and $>10$ years of negative interactions, respectively. Our findings concur with studies from Sri Lanka and Kenya, and parallel studies 
in India (Fernando et al., 2005; Sitati et al., 2005; Karanth \& Kudalkar, 2017). Species also appeared to play a role, with households more likely to use mitigation measures if they experienced crop damage by wild pigs, or livestock predation by wolves, jackals or leopards.

Unlike other states in India, Rajasthan does not have a statewide compensation scheme for crop and property damage (Karanth \& Gupta, unpubl. data), and the state's forest administration appears to have a lack of understanding of the levels of crop damage experienced by communities around reserves (Johnson et al., unpubl. data). Nonetheless, the low rates of compensation did not seem to influence the level of tolerance for wildlife among households, which was generally high. No household surveyed reported using killing as a way to mitigate humanwildlife interaction. However, continued economic losses could drive people to engage in retaliatory killing, as has occurred at other sites (Holmern et al., 2007). The lack of evidence regarding mitigation effectiveness is a cause for concern and necessitates further field-based evaluations. Compensation for losses incurred could partially ease the burden placed on people and increase their ability to cope with losses related to wildlife. This would require the Government of Rajasthan to improve its policies in line with most other Indian states, which routinely compensate people (Karanth \& Gupta, unpubl. data). In addition to policy improvements, people could also benefit from assistance in applying for compensation via conservation interventions such as the Wild Seve project in Karnataka, which has assisted 8,000 families file claims in 29 months, using mobile technology (K. Karanth, pers. obs.).

Our large sample size of 2,233 households decreases the possibility of bias caused by self-reporting of losses, and replicates well-established methodology from studies conducted in Central India and the Western Ghats (Karanth et al., 2012, 2013b). Further field-based research that monitors interaction and develops intervention mechanisms such as Wild Seve is essential to long-term conservation success. Our survey and modelling approaches are easily adaptable and replicable. Understanding people's attitudes towards wildlife and wildlife reserves, and estimating losses caused by wildlife, is a first step in developing locally relevant conservation interventions that sustain human livelihoods and promote tolerance towards wildlife in shared spaces.

\section{Acknowledgements}

We thank the Wildlife Conservation Society (WCS), the Indian Institute of Management Udaipur (IIMU), Nicholas School of Environment, Duke University, the Centre for Wildlife Studies, and the Rajasthan forest department. We acknowledge contributions from Anjana, Anubhav, Dhee, Dincy, Libby, Parvathi, Rachana, Rashmi, Shalini and
Vinod, and thank the volunteers Abhijeet, Achintya, Akanksha, Akhil, Amit, Archana, Avik, Bhaskar, Devendra, Dhwani, Durga, Gautam, Himanshu, Kaushiki, Lynette, Mayukh, Neha, Pranesh, Radhika, Sahila, Samyukta, Shashank, Shivona, Srinivasan, Sushmita, Tista and Tsongjing for their efforts in the field. We thank IIMU, Duke University and WCS for financial support.

\section{Author contributions}

KK developed the research questions, collected and analysed data and wrote the article. SJ analysed data and contributed to the writing. EW guided the research and contributed to the writing.

\section{References}

Bradley, E.H. \& Pletscher, D.H. (2005) Assessing factors related to wolf depredation of cattle in fenced pastures in Montana and Idaho. Wildlife Society Bulletin, 33, 1256-1265.

Browne-Nuñez, C., Jacobson, S.K. \& Vaske, J.J. (2013) Beliefs, attitudes, and intentions for allowing elephants in group ranches around Amboseli National Park, Kenya. Wildlife Society Bulletin, 37, 639-648.

Burnham, K.P. \& Anderson, D. (2002) Model Selection and Multimodel Inference: A Practical Information-Theoretic Approach. Springer-Verlag, New York, USA.

Chhangani, A.K., Robbins, P. \& Mohnot, S.M. (2008) Crop raiding and livestock predation at Kumbhalgarh Wildlife Sanctuary, Rajasthan India. Human Dimensions of Wildlife, 13, 305-316.

Davies, T.E., Wilson, S., Hazarika, N., Chakrabarty, J., Das, D., Hodgson, D.J. \& Zimmermann, A. (2011) Effectiveness of intervention methods against crop-raiding elephants. Conservation Letters, 4, 346-354.

Dhanwatey, H.S., Crawford, J.C., Abade, L.A.S., Dhanwatey, P. H., Nielsen, C.K. \& Sillero-Zubiri, C. (2013) Large carnivore attacks on humans in central India: a case study from the Tadoba-Andhari Tiger Reserve. Oryx, 47, 221-227.

Dickman, A.J. (2010) Complexities of conflict: the importance of considering social factors for effectively resolving human-wildlife conflict. Animal Conservation, 13, 458-466.

Fernando, P., Wikramanayake, E., Weerakoon, D., Jayasinghe, L.K.A., Gunawardene, M. \& Janaka, H.K. (2005) Perceptions and patterns of human-elephant conflict in old and new settlements in Sri Lanka: insights for mitigation and management. Biodiversity and Conservation, 14, 2465-2481.

Fisher, M. (2016) Whose conflict is it anyway? Mobilizing research to save lives. Oryx, 50, 377-378.

Gore, M.L. \& KAHLeR, J.S. (2012) Gendered risk perceptions associated with human-wildlife conflict: implications for participatory conservation. PLoS ONE, 7(3), e32901.

Government OF India (2011) Primary census abstract [data file]. Http:// www.censusindia.gov.in/pca/default.aspx [accessed 14 July 2016].

Government of India (2012) 19th livestock census [data file]. Http:// animalhusbandry.rajasthan.gov.in/livestock_census.aspx [accessed 14 July 2016]

Holmern, T., Nyahongo, J. \& Røskaft, E. (2007) Livestock loss caused by predators outside the Serengeti National Park, Tanzania. Biological Conservation, 135, 518-526. 
KARANTH, K.K. (2016) Wildlife in the matrix: spatio-temporal patterns of herbivore occurrence in Karnataka, India. Environmental Management, 57, 189-206.

Karanth, K.K., Gopalaswamy, A.M., DeFries, R. \& Ballal, N. (2012) Assessing patterns of human-wildlife conflicts and compensation around a Central Indian Protected Area. PLoS ONE, 7(12), e50433.

Karanth, K.K., Gopalaswamy, A.M., Prasad, P.K. \& Dasgupta, S. (2013a) Patterns of human-wildlife conflicts and compensation: insights from Western Ghats protected areas. Biological Conservation, 166, 175-185.

KarAnth, K.K. \& KUDAlKaR, S. (2017) History, location, and species matter: insights for human-wildlife conflict mitigation from India. Human Dimensions of Wildlife, http://dx.doi.org/10.1080/10871209. 2017.1334106.

Karanth, K.K., Naughton-Treves, L., Defries, R. \& Gopalaswamy, A.M. (2013b) Living with wildlife and mitigating conflicts around three Indian protected areas. Environmental Management, 52, 1320-1332.

Karanth, K.K. \& Nepal, S.K. (2012) Local residents' perception of benefits and losses from protected areas in India and Nepal. Environmental Management, 49, 372-386.

Karanth, K.K., Nichols, J.D., Karanth, K.U., Hines, J.E. \& Christensen, N.L. (2010) The shrinking ark: patterns of large mammal extinctions in India. Proceedings of the Royal Society B, 277, 1971-1979.

Karanth, K.K. \& Surendhra, A. (2018) Species and sites matter: understanding human-wildlife interactions from 5000 surveys in India. In Conservation and Development in India: Reimagining Wilderness (ed. Shonil Bhagwat), pp. 61-82. Routledge, Abingdon, UK.

KIssui, B.M. (2008) Livestock predation by lions, leopards, spotted hyenas, and their vulnerability to retaliatory killing in the Maasai steppe, Tanzania. Animal Conservation, 11, 422-432.

Michalski, F., Boulhosa, R.L.P., Faria, A. \& Peres, C.A. (2006) Human-wildlife conflicts in a fragmented Amazonian forest landscape: determinants of large felid depredation on livestock. Animal Conservation, 9, 179-188.

NASA (2011) AsterGDEM version 2. NASA Land Processes Distributed Active Archive Center, USGS Earth Resources Observation and Science (EROS) Center, Sioux Falls, USA. Https:// lpdaac.usgs.gov [accessed 14 July 2016].

National Remote Sensing Centre (2014) Multi-temporal satellite data of 2011-12 from Resourcesat-2 LISS III. Http://bhuvan.nrsc.gov. in/gis/thematic/index.php [accessed 14 July 2016].
Naughton-Treves, L. \& Treves, A. (2005) Socio-ecological factors shaping local support for wildlife: crop-raiding by elephants and other wildlife in Africa. In People and Wildlife: Conflict or Coexistence? (eds R. Woodroffe, S. Thirgood \& A. Rabinowitz), pp. 252-277. Cambridge University Press, Cambridge, UK.

Ogada, M.O., Woodroffe, R., Oguge, N.O. \& Frank, L.G. (2003) Limiting depredation by African carnivores: the role of livestock husbandry. Conservation Biology, 17, 1521-1530.

Ogra, M. \& BADOLA, R. (2008) Compensating human-wildlife conflict in protected area communities: ground-level perspectives from Uttarakhand, India. Human Ecology, 36, 717-729.

Pearson, K. (1895) Note on regression and inheritance in the case of two parents. Proceedings of the Royal Society of London, 58 , $240-242$.

Redpath, S.M., Bhatia, S. \& Young, J. (2015) Tilting at wildlife: reconsidering human-wildlife conflict. Oryx, 49, 222-225.

Robbins, P., McSweeney, K., Chhangani, A.K. \& Rice, J.L. (2009) Conservation as it is: illicit resource use in a wildlife reserve in India. Human Ecology, 37, 559-575.

Sitati, N.W., Walpole, M.J. \& Leader-Williams, N. (2005) Factors affecting susceptibility of farms to crop raiding by African elephants: using a predictive model to mitigate conflict. Journal of Applied Ecology, 42, 1175-1182.

Treves, A., Jurewicz, R.L., Naughton-Treves, L. \& Wilcove, D.S. (2009) The price of tolerance: wolf damage payments after recovery. Biodiversity and Conservation, 18, 4003-4021.

Woodroffe, R., Frank, L.G., Lindsey, P.A., ole Ranah, S.M.K. \& ROMAÑACH, S. (2007) Livestock husbandry as a tool for carnivore conservation in Africa's community rangelands: a case-control study. Biodiversity and Conservation, 16, 1245-126o.

Zhang, W., Ricketts, T.H., Kremen, C., Carney, K. \& Swinton, S. M. (2007) Ecosystem services and dis-services to agriculture. Ecological Economics, 64, 253-260.

\section{Biographical sketches}

Krithi KaRANTH studies species distributions, wildlife tourism, human-wildlife conflicts, voluntary resettlement and land-use change. SHIVANGI JAIN is a social scientist interested in natural resource governance, sustainable livelihoods and environmental economics. ER IK A WEINTHAL's research interests include global environmental politics and governance, political economy of resource use, and climate change adaptation. 